\title{
PENELUSURAN PROTOTIPE PEMIKIRAN ISLAM FAISAL ISMAIL DAN PROBLEM YANG MENGHADANG
}

\author{
Oleh: Mujamil Qomar
}

(Guru Besar Islamic Studies IAIN Tulungagung)

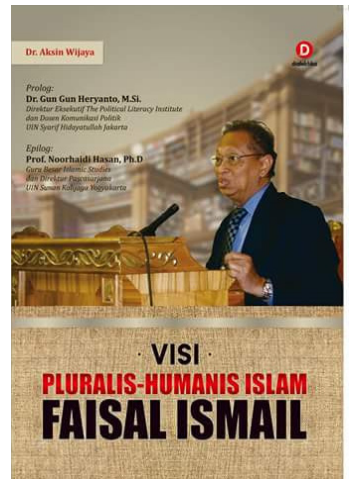

\author{
Judul : Visi Pluralis-Humanis Islam \\ Faisal Ismail \\ Penulis : Dr. Aksin Wijaya \\ Penerbit : Dialektika \\ Kota : Yogyakarta \\ Tahun : 2017 \\ Jumlah : 290 \\ ISBN : 978-602-60398-1-1
}

Buku yang berjudul Visi Pluralis-Humanis Islam Faisal Ismail ini merupakan hasil final dari upaya Aksin Wijaya dalam menelusuri dan menformulasikan model pemikiran Islam Faisal Ismail yang tersebar di berbagai media baik buku, jurnal, majalah, antologi maupun surat kabar. Tidak berlebihan jika dikatakan bahwa prototipe pemikiran Faisal Ismail sebagai pluralis-humanis ini sebagai hasil "Ijtihad Ilmiah" dari intelektual muslim asal Sumenep Madura ini.

Judul buku ini cukup menarik perhatian terutama pada kata pluralis yang seakar kata dengan pluralisme. Sebagai sebuah konsep, pluralisme yang digagas antara lain oleh Harold Coward ${ }^{1}$ ini di Indonesia pernah menimbulkan kontroversi yang sangat tajam antara Majelis Ulama Indonesia (MUI) dengan pemikir Islam liberal. MUI bahkan mengharamkan pluralisme itu, sedangkan pemikir Islam

1 Harold Coward, Pluralism in the World Religions: A Short Introduction (England: Oneworld Oxford, 2000). 
liberal memandang sebagai suatu keniscayaan sejarah yang tidak mungkin dihindarkan terutama dalam kehidupan global sekarang ini di mana arus interaksi pergaulan umat manusia semakin kompleks. Dengan kata lain, sebenarnya pluralisme merupakan sunnatullah. Faisal Ismail sendiri juga dalam buku ini telah mengritik fatwa MUI tersebut, meskipun dia bukan pemikir Islam liberal.

Tulisan dalam buku ini sesungguhnya merupakan upaya membaca, mencermati, menyimpulkan, dan menegaskan formulasi identitas sebuah prototipe pemikiran Islam Faisal Ismail. Suatu upaya yang relatif sulit lantaran pemikiran seseorang itu seringkali merefleksikan prototipe yang ganda. Misalnya, Imam Al-Ghazali oleh kalangan konservatif dinilai liberal tetapi oleh kalangan liberal dinilai konservatif; Al-Ghazali oleh kalangan tertentu dianggap antiintelektualisme namun menurut kalangan lainnya justru dipandang sebagai intelektual Muslim kaliber dunia; dan berdasarkan kitabnya, Tahafut al-Falasifah, al-Ghazali dipersepsi sebagai pemikir Islam yang anti-filsafat, namun kelompok lainnya justru mempersepsinya sebagai pemikir Islam yang mendalami dan terpengaruh oleh filsafat Yunani berdasarkan karya al-Ghazali lainnya, seperti Mi'yar al-' $\mathrm{Ilm}$, al-Mustashfa min 'Ilm al-Ushul dan al-Qisthas al-Mustaqim. Sosok Gus Dur juga bisa dikategorikan sebagai pemikir tradisional, modernis, neomodernis, substantivistik, pluralis, kosmopolit, divergen, bahkan liberal. Demikian juga, prototipe pemikiran Faisal Ismail juga tidak mudah dirumuskan secara utuh dan tuntas, mengingat masih muncul bayang-bayang prototipe lainnya kendatipun tidak sekompleks alGhazali maupun Gus Dur.

Kesulitan merumuskan prototipe pemikiran seperti yang dilakukan oleh Aksin Wijaya ini, makin terasa setelah dia menghadapi setidaknya empat hal: substansi pemikiran yang dikaji, metode atau pendekatan yang digunakan oleh tokoh yang dikaji, karakteristik pemikiran yang dikaji, dan kategorisasi atau prototipe pemikiran yang dikaji. Tambahan 
lagi, yaitu metode atau pendekatan yang dipakai oleh pengkaji sendiri. Kesulitan menangkap substansi pemikiran yang sedang dikaji karena pengkaji harus mencermati berbagai pemikiran seorang tokoh yang berserakan dan terkadang tidak sambung bahkan bertentangan; kesulitan menangkap metode atau pendekatan yang digunakan karena seringkali tokoh yang dikaji tidak menyebutkan jenis metode atau pendekatannya, dan jika misalnya dia menyebutkannya juga seringkali tidak jelas; kesulitan menangkap karakteristik pemikiran juga terjadi karena pengkaji harus mampu membedakan pemikiran yang sedang dikaji dengan pemikiran-pemikiran tokoh lainnya yang begitu banyak dan tidak jarang terjadi kemiripan-kemiripan; sedangkan kesulitan menangkap kategori atau prototipe pemikiran yang dikaji -- sebagaimana di depan telah disebutkan - karena suatu pemikiran seringkali mencerminkan wajah ganda, dan banyaknya sudut pandang yang dijadikan untuk memotret pemikiran seseorang. Metode atau pendekatan yang digunakan oleh pengkaji sendiri juga ikut mempersulit perumusan prototipe pemikiran seseorang tokoh karena seringkali terjebak dalam subjektivitas, sehingga pemahaman pengkaji terhadap pemikiran tokoh berbeda jauh dengan yang dimaksudkan oleh tokoh itu sendiri.

Empat macam problem ini sekaligus sebagai tahapan dalam merumuskan prototipe pemikiran sesorang tokoh tersebut sehingga menuntut keseriusan pengkaji. Problem pertama terkait dengan substansi pemikiran Faisal Ismail telah berhasil dilalui oleh Aksin Wijaya dengan keberhasilannya menjelajahi dan mendalami berbagai pemikiran Faisal Ismail yang tersebar pada berbagai media kemudian mengambil intisarinya. Aksin Wijaya telah mengumpulkan dan menelaah isi/kandungan karya-karya Faisal Ismail mulai dari karya berbentuk puisi, sajak-sajak, pemikiran, maupun kritik yang menggugat pemikiran tokoh-tokoh tertentu, yang termuat baik dalam majalah, jurnal, koran, antologi, tesis, disertasi, buku ajar, buku ilmiah, 
makalah, dan artikel populer.

Beberapa ilustrasi pemikiran Faisal Ismail telah dipaparkan oleh Aksin Wijaya dalam buku yang ada di tangan pembaca ini. Misalnya, Faisal Ismail telah berusaha mendudukkan perbedaan tiga istilah kunci yang seringkali menimbulkan kesalahpahaman yaitu modernisasi, westernisasi, dan sekularisasi. ${ }^{2}$ Pengertian modernisasi tidak sama dengan westernisasi. Jika proses westernisasi mengandung proses sekularisasi, maka tidaklah demikian dengan modernisasi. ${ }^{3}$ Kebudayaan Barat tidak serta merta mesti modern. ${ }^{4}$ Modernisasi memang bayak dipraktikkan oleh orang-orang Barat, tetapi modernisasi bukan monopoli Barat dan Barat juga tidak identik dengan modernisasi. Modernisasi bisa terjadi di belahan bumi mana pun. ${ }^{5}$ Apalagi jika modernisasi dikaitkan dengan tradisi. Turki pada masa Kemal Ataturk ternyata gagal mencapai kemajuan seperti yang dicapai oleh beberapa Negara Barat kendati tradisi-tradisi Islam telah dibabat habis guna mengikuti secara taat model kehidupan Barat, karena yang ditempuh oleh Turki ternyata bukan mengambil modernisasi Barat melainkan justru terjebak pada westernisasinya. Sebaliknya, Jepang meskipun negeri sakura ini sangat kuat mempertahankan tradisinya, ternyata Jepang justru mampu mengungguli kemajuan Barat di bidang teknologi elektro. Sebab Jepang merupakan raja teknologi elektro di dunia ini.

Kenyataan ini menunjukkan bahwa westernisasi tidak identik dengan modernisasi. Selanjutnya modernisasi tidak selalu berbenturan dengan tradisi. Di kalangan ulama, hubungan tradisi dan modernisasi itu telah dirumuskan dengan sangat ideal melalui slogan al-muhafadhah 'ala al-qadim al-shalih wa al-akhdzu bi al-jadid al-ashlah (memelihara

2 Faisal Ismail, Paradigma Kebudayaan Islam: Studi Kritis dan Analisis Historis (Yogyakarta: Suka Press, 2014), hlm. 327.

3 Ibid., hlm. 330.

4 Faisal Ismail, Islam: Melacak Teks Menguak Konteks (Yogyakarta: Titian Wacana, 2009), hlm. 207-208.

5 Mujamil Qomar, "Sinergisme Tradisi dengan Modernisasi dalam Pemikiran Islam Kontemporer," Empirisma, vol. 23, no. 1 Januari 2014, hlm. 7. 
hal-hal lama yang baik, dan mengambil hal-hal baru yang lebih baik). Al-muhafadhah 'ala al-qadim al-shalih mencerminkan sikap kita terhadap tradisi, sedang al-akhdzu bi al-jadid al-ashlah mencerminkan sikap kita terhadap modernisasi. Rumusan ini mensyaratkan kualitas yang baik pada tradisi dan kualitas yang lebih baik pada modernisasi. Maka harus ada seleksi pada tradisi dan modernisasi. Tidak semua tradisi kita pertahankan, dan tidak semua modernisasi dapat kita ambil. ${ }^{6}$ Hanya saja, Faisal Ismail -menurut penilaian Aksin Wijayaagak condong pada pandangan Barat yang mempertentangkan antara modernisasi dengan tradisi.

Ilustrasi berikutnya yang terkait dengan pemikiran Faisal Ismail adalah tentang multikulturalisme dan pluralisme. Faisal Ismail mendefinisikan multikulturalisme sebagai paham atau pandangan yang mengakui dan menghargai realitas multikultur dalam kehidupan masyarakat. Sedangkan pluralisme adalah "prinsip yang menganggap bahwa orang-orang dari berbagai ras, agama, dan pandangan politik dapat hidup berdampingan secara damai dalam masyarakat yang sama." J Jadi pluralisme dipertegas oleh Faisal Ismail hanya sekedar "prinsip pengakuan" terhadap keberagaman ras, agama dan pandangan politik dalam masyarakat, sama sekali tidak dimaksudkan sebagai "pengakuan terhadap kebenaran semua agama”.

Dan juga, Faisal Ismail menyatakan bahwa doktrin atau ajaran Islam yang bersumber dari wahyu Allah tidak mengandung unsur atau bagian dari kebudayaan Islam, tetapi justru pengamalan umat Islam terhadap ajaran agamanya yang membentuk kebudayaan. Jadi agama Islamlah yang membentuk kebudayaan. ${ }^{8}$ Bukan sebaliknya,

6 Mujamil Qomar, Merintis Kejayaan Islam Kedua Merombak Pemikiran dan Mengembangkan Aksi (Yogyakarta: Teras, 2011), hlm. 174.

7 Faisal Ismail, Republik Bhinneka Tunggal Ika: Mengurai Isu-isu Konflik, Multikulturalisme, Agama dan Sosial Budaya (Jakarta: Badan Litbang Agama dan Diklat Keagamaan, Kementerian Agama RI, 2012), hlm.37.

8 Ismail, Paradigma Kebudayaan, hlm. 98. 
kebudayaan yang membentuk Islam. Pemikiran Faisal Ismail ini dalam konteks mengritisi pemikiran Sidi Gazalba yang menyatakan "Islam adalah agama dan kebudayaan.” Faisal Ismail benar karena paradigma berpikirnya adalah Islam sebagai wahyu sedangkan kebudayaan sebagai produk akal, sehingga memunculkan pernyataan berikutnya, tidak ada unsur-unsur kebudayaan yang membentuk ajaran Islam.

Problem kedua terkait dengan metode atau pendekatan yang digunakan Faisal Ismail. Menghadapi problem ini Aksin Wijaya agak terbantu karena Faisal Ismail secara ekplisit telah menyebut istilah kritis-apresiatif dan apresiatif-kritis. Hanya saja penyebutan keduanya masih menyisakan pertanyan di benak pembaca, apakah keduanya sebagai pandangan, metode, pendekatan atau sekadar sikap? Apakah istilah kritis-apresiatif maupun apresiatif-kritis itu dimaksudkan sebagai struktur kata yang terdiri atas kata sifat beserta kata yang disifati (na'at-man'ut maupun shifat-maushuf) atau frase yakni gabungan dua kata atau lebih yang tidak menimbulkan arti baru (mudhaf-mudhaf ilaih)? Kemudian yang ditonjolkan oleh Faisal Ismail, apakah pada kritis-apresiatif atau sebaliknya, apresiatif kritis? Pertanyaan-pertanyaan ini harus diperjelas oleh Aksin Wijaya, karena semua penekanan memiliki konsekuensi dan implikasinya masingmasing.

Problem ketiga terkait dengan karakteristik pemikiran Faisal Ismail. Di sini Aksin Wijaya dituntut membandingkan pemikiran Faisal Ismail dengan pemikiran tokoh-tokoh lainnya, dan pada tahapan ini harus berhadapan dengan sekian banyak pemikir Islam, setidaknya dengan sesama pemikir Islam yang berasal dari Indonesia. Dalam hal ini Aksin Wijaya telah membedakan pemikiran Faisal Ismail dengan Sidi Gazalba tentang hukum sekularisasi Islam, dengan Nurcholish Madjid tentang sekularisasi Islam, dengan Ahmad Wahib tentang sekularisasi al-Qur'an, dan dengan A. Qodri Azizi tentang humanisasi-sakralisasi ilmu. Pemikiran Faisal Ismail juga berbeda dengan pemikiran 
pimpinan MUI dalam hal menghadiri perayaan Natal dan pluralisme agama. Demikian juga sebaliknya, Aksin Wijaya berhasil menunjukkan kesamaan pemikiran Faisal Ismail dengan Naquib al-Attas dalam menolak ide sekularisasi pada segala manifestasi dan bentuknya yang dikaitkaan dengan Islam. Namun, apakah pemikir Muslim Malaysia yang pemikirannya sama atau mirip dengan pemikiran Faisal Ismail itu hanya terbatas pada seorang Naquib al-Attas tersebut? Dalam tahapan inilah, pengkaji mendapatkan tantangan yang cukup berat, khususnya dalam memotret pemikiran Faisal Ismail.

Problem keempat terkait dengan kategorisasi atau prototipe pemikiran Faisal Ismail. Tahapan ini merupakan tahapan paling sulit yang dilalui oleh Aksin Wijaya, sebab tahapan ini mendasarkan pada tahapan ketiga yang berusaha mengidentifikasi karakteristik pemikiran Faisal Ismail. Jika identifikasi ini kurang tepat, akan berpengaruh terhadap penyimpulan prototipe pemikiran intelektual asal Madura ini yang oleh Aksin Wijaya disebut intelektual kelana. Di samping itu, tahapan ini merupakan hasil terakhir dari penelusuran panjang Aksin Wijaya yang diharapkan merefleksikan substansi temuannya dalam membingkai pemikiran-pemikiran seorang pemikir Islam yang pernah menjadi Sekretaris Jenderal Departemen Agama dan Duta Besar untuk Kuwait merangkap Bahrain tersebut, sehingga prototipe pluralis-humanis Islam itu benar-benar sebagai miniatur pemikiran Faisal Ismail.

Prototipe pluralis-humanis Islam ini memancing suatu pertanyaan yang cukup mengganggu bagi Aksin Wijaya sebagai pengkaji. Apakah pemikiran Islam Faisal Ismail sudah tepat dikategorikan sebagai pluralis-humanis Islam? Apakah pemikiran Islam Faisal Ismail hanya dapat dikategorikan sebagai pluralis-humanis Islam? Apakah tidak ada tipe-tipe lainnya yang lebih cocok dengan model pemikiran Islam Faisal Ismail daripada pluralis-humanis Islam? Atas dasar sudut pandang apakah (perspektif sifat pemikiran, corak pemikiran, objek 
pemikiran, atau perspektif-perspektif lainnya) sehingga pemikiran Islam Faisal Ismail tergolong pluralis-humanis Islam? Mungkinkah prototipe pluralis-humanis Islam bagi pemikiran Islam Faisal Ismail diganti prototipe lainnya? Pertanyaan-pertanyaan ini cukup mengusik, manakala penetapan prototipe pluralis-humanis Islam tidak memiliki dasar yang kokoh dan parameter yang jelas.

Tampaknya, penyimpulan prototipe pemikiran pluralis-humanis Islam ini oleh Aksin Wijaya lebih didasarkan pada perspektif objek pemikirannya daripada perspektif-perspektif lainnya yang biasanya lebih menonjolkan unsur subyektif pengkaji. Untuk memperkuat penyimpulan prototipe pemikiran Islam Faisal Ismail sebagai pluralis-humanis Islam, Aksin Wijaya mendasarkan pada delapan prinsip yang dia sebut sebagai manifesto pemikiran keislaman dan keindonesiaan Faisal Ismail. Delapan prinsip ini meliputi: 1) muslim pluralis-humanis mengakui dan menghargai adanya keberagaman baik dalam hubungan intra-agama maupun antaragama;2) muslim pluralis-humanis memandang manusia seagama dan manusia di luar agamanya sebagai "kawan", bukan sebagai lawan; 3) muslim pluralis-humanis menaruh "respek dan hormat" kepada orang seagama dan orang yang berbeda agama; 4) muslim pluralis-humanis menghargai dan merealisasikan toleransi dan harmoni antarumat beragama; 5) muslim pluralis-humanis memahami teks-teks kitab suci agama tidak bersifat hitam-putih, tekstualis-skripturalis, tidak rigit, tidak kaku, tidak sempit, dan tidak eksklusif; 6) muslim pluralishumanis mengedepankan agenda kemanusiaan bersama dalam kehidupan berbangsa dan bernegara; 7) muslim pluralis-humanis mengedepankan dialog antarumat beragama, sehingga suatu persoalan yang menyangkut hubungan antarumat beragama diharapkan dapat terpecahkan melalui musyawarah secara adil dan damai, yang diterima oleh komunitas-komunitas agama peserta dialog itu; dan 8) muslim pluralis-humanis lebih mengedepankan dan mengutamakan saluran 
institusi-institusi pendidikan daripada saluran institusi/partai politik (formalisme syariah atau formalisasi Islam) dalam menyebarluaskan nilai-nilai Islam dalam kehidupan masyarakat. ${ }^{9}$

Di samping itu, pendekatan yang ditempuh oleh pengkaji sendiri terkadang menyumbangkan kesimpulan yang bias terhadap pemikiran tokoh yang dikaji. Hanya saja, Aksin Wijaya sangat tepat dalam menggunakan pendekatan dalam kajian ini yang dia sebut dengan membaca Faisal Ismail melalui Faisal Ismail. Dengan pengertian lain, pendekatan ini adalah memahami pemikiran Faisal Ismail melalui alur berpikirnya. Pendekatan ini tepat sekali setidaknya dalam mengurangi subjektivitas pengkaji dan mempertegas pemikiran Faisal Ismail sebagai objek kajian menurut jalan pikirannya sendiri. Pendekatan ini mengingatkan saya pada sosok Prof. Harun Nasution ketika membedah suatu pemikiran: ketika mengkaji filsafat, dia seperti filosof; ketika membahas tasawuf, dia laksana sufi; ketika membahas ilmu kalam, dia seperti mutakallim; secara lebih spesifik ketika membahas aliran Khawarij, dia seperti Khariji; ketika membahas aliran Murjiah, dia seperti Murji i; ketika membahas aliran Jabariyah, dia seperti Jabari; ketika membahas aliran Qadariyah, dia seperti qadari; ketika membahas Mu’tazilah, dia merefleksikan diri seperti Mu'tazili; ketika membahas aliran Syi'ah, dia seperti Syi'i; dan ketika membahas aliran Ahlussunnah waljama’ah, dia tampak seperti Sunni. Karena itu, mahasiswa yang memperhatikan uraiannya merasakan kesulitan di mana posisi Harun Nasution tersebut.

Seandainya Aksin Wijaya menggunakan perspektifnya sendiri yang subyektif mungkin banyak penafsiran dan analisis terhadap pemikiran Islam Faisal Ismail yang "liar", memaksakan maksud maupun makna pemikiran Islam sesuai dengan kehendaknya sendiri, dan menyimpang dari maksud-maksud yang dikehendaki oleh Faisal Ismail sendiri.

9 Ismail, Republik Bhinneka, hlm. 172-176. Lihat juga Faisal Ismail, Dinamika Kerukunan Antarumat Beragama (Bandung: PT. Remaja Rosdakarya, 2014), hlm. 28-30. 
Namun model pendekatan yang "menyesatkan" ini sama sekali tidak pernah ditempuh oleh Aksin Wijaya sebagai bukti bahwa dia telah mampu berdiri tegak dalam kapasitasnya sebagai pengkaji pemikiran Islam seorang Faisal Ismail. Sikap yang sangat tepat ini disebabkan karena lulusan doktor tercepat dan terbaik UIN Sunan Kalijaga Yogyakarta pada periodenya ini telah memiliki pengalaman panjang sebagai penulis maupun peneliti, di samping itu juga lantaran dia telah berkenalan dengan metodologi penelitian maupun metodologi pengkajian modern dari para ilmuan Barat secara intensif.

Dengan demikian, terlepas masih terdapat kesulitan-kesulitan tertentu dalam mendefinisikan saripati pemikiran Islam Faisal Ismail yang tentu saja melampaui temuan Aksin Wijaya, yang jelas secara umum Aksin Wijaya telah berhasil mengatasi problem-problem yang mengganggu selama melakukan kajian mendalam terhadap pemikiran Faisal Ismail tersebut. Keberhasilan Aksin Wijaya ini tidak lepas dari komitmennya yang tinggi dalam upayanya menghadirkan dan mempertegas prototipe pemikiran Islam Faisal Ismail, seorang pemikir Islam dari Madura yang karya-karya dan pemikiran-pemikirannya yang tajam layak mendapatkan perhatian publik Indonesia. Karyakarya dan pemikiran-pemikiran ini merupakan kontribusi yang sangat besar dari Faisal Ismail terutama dalam membangun kehidupan beragama, berbangsa dan bernegara yang penuh rasa toleran, damai, sejuk dan harmonis.

Akhirnya, menurut pengamatan saya, buku yang ada di tangan pembaca ini sangat layak untuk dibaca, ditelaah, dan diteliti terutama bagi pelajar, mahasiswa, guru, dosen, muballigh, da'i, khatib dan pemerhati pluralisme maupun humanisme Islam untuk memahami hakekat pluralisme dan humanisme Islam tersebut. Di samping itu, buku ini juga sangat bermanfaat ketika digunakan sebagai panduan bagi umat Islam dalam kehidupan beragama, berbangsa dan bernegara di mana saja, khususnya di negara-negara yang kondisi populasinya 
plural sekali seperti Indonesia ini. Apalagi buku ini telah disusun oleh sorang penulis yang berpengalaman dengan narasi yang sistematis. Kepada penulisnya, saudara Aksin Wijaya, semoga sukses dan selamat berkarya lagi. 
